\title{
Globalizing Literary History
}

\author{
JOHN NEUBAUER
}

\begin{abstract}
In the last decades, national and transnational literary histories have continued to take different approaches. The typical new national literary histories have discarded the teleology of grand narratives by chopping up the chronological line into individual essays on specific subjects, each attached to a single date. They compensate for the temporal disintegration with a cultural broadening of literature's scope and occasional international references. The transnational counter trend has been producing regional histories (of Latin America, East-Central Europe, the Iberian Peninsula and Scandinavia), a history of literature in the European languages sponsored by the ICLA, and schemes for global approaches. Moving towards globalization poses the problem of coordinating vast and divergent empirical information. Two suggestions may help moving towards global perspectives: 1) replace the traditional period concepts with landmarks based on the introduction of new writing technologies, and 2) conceive of literary and cultural history as a sequence of adaptations. The latter may offer opportunities to interlink culture and biology.
\end{abstract}

Keywords: literary history, regionalization, globalization, adaptation

DOI: http://dx.doi.org/10.12697/IL.2013.18.1.01

\section{National Histories of Literature}

Friedrich Schlegel, a leading German romantic thinker, started to write the first literary histories in the last years of the eighteenth century. His brother August Wilhelm Schlegel broadened these first comparative and transnational attempts, but the wars against Napoleon inspired Friedrich's last and most important literary history, which is broadest in scope but nationalist in his conception. His 1812 series of lectures in Vienna titled Geschichte der alten und neuen Literatur (History of the Old and the New Literature) briefly touched on Hebrew and Persian literature, and, based on Schlegel's study of Sanskrit, included a chapter on ancient Indian literature. The lectures bypassed Chinese literature, whose first histories in European languages - Herbert Giles' History of Chinese Literature (1901) and Wilhelm Grube's Geschichte der chinesischen 
NEUBAUER

Literatur (History of Chinese Literature, 1902) - appeared almost a century later. Friedrich Schlegel's initiative to globalize literary history was, however, also a decisive step towards nationalism, for he narrowed his conception by defining literature as the embodiment of a nation's intellectual life. Earlier he believed that the national elements of modern literature could only be comprehended within a larger totality, but now he proclaimed that poetry's foremost task was to recall a nation's distant origins, and glorify, as well as preserve, those national memories that were indispensable for a nation's spiritual existence (10-16).

This national conception and justification of literature became the foundation of literature's national institutionalization in nineteenth-century Europe. All European nations gradually introduced the teaching of their national literature in the schools and at the universities; university chairs were established for the vernacular literature; and the appointed professors were expected to write histories of the national literature for educational purposes. Simultaneously, National Theaters, National Academies, publishers, and other literary institutions were founded to cultivate and promote this native literature. Most nineteenth-century national histories closely linked literature to social, political, and national events, usually in the spirit of Hippolyte Taine's triple concept of "race, milieu, and moment" (see Wellek Modern Criticism, 4: 27-57) and Hegel's notion of a Zeitgeist, the idea that all social and artistic phenomena of an age express a common spirit. The Hegelian idea of Zeitgeist furthered the periodization of literary history and suggested the use of periods like Romanticism and Realism, which covered more than literature proper by including the other arts and cultural phenomena. Nineteenth-century national literary histories of Gervinus, Lanson, Taine, Chlebowski, De Sanctis, and Beöthy in my final "References" helped forging national identities, but they excluded minorities and often created schematic unities at the cost of individualism and variety. Individual literary works were often forced into period concepts that did not do justice to their richness. Reading literature within such preconceived national and period concepts did not encourage readers to focus at the linguistic and stylistic aspects of the texts.

The first major attack on such schematizations of literature came from the Russian formalists, who questioned periodization and references to a Zeitgeist. In a 1927 article titled "On Literary Evolution," Yuri Tynyanov proposed that literary history was a series of temporal shifts from system to system, amounting to what he called a "literary series" in literary evolution (459). Though he admitted that the literary series should later be correlated with non-literary series in the other arts, culture, and social life, he minimized the role of a Zeitgeist by foregrounding a timeline based on literature alone. This approach was 
adopted by René Wellek, a literary scholar born in Czechoslovakia who immigrated to the United States and introduced there after World War II the study of comparative literature. According to the famous Theory of Literature he published with Austin Warren in 1948, there could be no objection if the results of literary historians "should coincide with those of political, social, artistic, and intellectual historians," but "our starting-point must be the development of literature as literature" (264).

The Tynyanov/Wellek theory did not inspire outstanding new literary histories, and nearly two more decades had to pass before it came under serious attack from Germany, where the werkimmanent approach, exclusive focus on text, dominated after the war. Hans Robert Jauss opened his 1967 inaugural lecture Literaturgeschichte als Provokation der Literaturwissenschaft (Literary History as a Provocation of Literary Scholarship) with the lapidary but devastating remark: "Literary history has fallen in our time into increasing, but by no means undeserved, disrepute" (144). He regarded not only the traditional literary histories responsible for this, but also Marxism and Formalism, which dominated post-war literary histories in East- and West-Germany respectively. Jauss gave credit to Tynyanov's notion of evolution (166), but proceeded to outline a reception concept that interlinks the literary and social series via the experience of readers and their dialogue with literary works $(167,171)$.

Wellek, among the first American theorists to respond to Jauss, opened his famous "The Fall of Literary History" (1973) by citing Jauss' statement, but he dismissed reception theory as déjà vu, a mere rehashing of "a history of taste that has always been included in a history of criticism" (77). Nevertheless, Wellek admitted that he may have made in Theory of Literature a "possibly oversharp distinction between extrinsic and intrinsic methods," which led to an isolation of works of art in history (67). The gloomy ending of Wellek's article was often taken as an epitaph for literary history, but the article surrendered only two of the presuppositions he adopted from Tynyanov: literary histories ought to rely solely on intrinsic criteria and such literary series constitute an evolution. Wellek particularly regretted that he found no evolution in his history of criticism: "I myself have failed in The History of Modern Criticism to construe a convincing scheme of development. I discovered, by experience, that there is no evolution in the history of critical argument." (77) Typical of the ensuing crisis was the question that David Perkins posed in 1992 with the much-discussed title of his book: Is Literary History Possible? His skepticism was reinforced by post-structuralist and deconstructive theories, which attacked histories with teleological destinies, and questioned both organicist conceptions of history and the possibility of writing grand historical narratives. However, reception theory, Michel Foucault’s genetic history, New 
NEUBAUER

Historicism, and cultural history have opened new historical approaches to literature by the time Perkins' book appeared. In the following discussion, I shall indicate how national and transnational literary histories reacted to the crisis of history writing.

Within national literary histories, the prominent reaction to the crisis of grand narratives has become simply to abandon continuous historical narrations. The trend was set by Denis Hollier's history of French literature, whose methodology has since been adopted in a Dutch/Flemish history edited by M. A. Schenkenveld-van der Dussen (1993), a Francophone Belgian one edited by Jean-Pierre Bertrand (2002), a German one edited by David Wellbery (2004), a Hungarian one edited by Mihály Szegedy-Maszák (2007), and an American one edited by Greil Marcus and Werner Sollors (2009). They all replace the continuous narrative thread of literary history with chronologically ordered independent essays (two-hundred-six in Hollier's French edition), each of which is attached to the date of an event that closely or distantly relates to literature. Thus, for instance, an article with the heading "Pour le profane," linked to the date December 5, 1905, refers to a vote in the National Assembly on the Separation of Church and State, and it alerts readers to related entries, dated 1808, 1898, and January 9, 1959. Hollier's scheme disperses writers, works, and themes over several unconnected articles and it avoids the use of historical periods in the hope that the shortened time scale of the articles will allow more encounters, convergences, and mutations ( $\mathrm{xx})$. By these and other means, Hollier wanted to achieve a "heterogeneity that escapes the linearity of traditional literary histories" (xix). Cross references are made here only within a single article. Hollier admits this loss of historicity by dropping the word "history" from the French title De la littérature française. In short, this type of approach cuts up literary history, and partly compensates for this by linking literature to contemporaneous cultural and international events.

\section{European Literary Histories}

National literary histories dominated the nineteenth and the first half of the twentieth century, and only few significant comparative literary histories were published. This changed when the International Comparative Literature Association, founded in 1955, established in 1967 a Coordinating Committee with the charge to publish a series with the somewhat curious title "A Comparative History of Literatures in European Languages." The formulation offered the possibility of going beyond geographically defined Europe to include, in principle, literatures from North and South America, Australia and other parts of 
the world where a European language was officially recognized. Indeed, the series came to include a two volume African history titled European language Writing in Sub-Saharan Africa (1986), edited by Albert Gérard, and a three-volume History of Literature in the Caribbean (1994-2001), edited by James Arnold.

The core of the still incomplete series is a multivolume literary history of a geographically defined Europe, which is chronologically divided into periods and movements, each of which is covered by one or several volumes. The latter is the case with the Renaissance and Romanticism. There are no volumes yet on the literature of Classical Greece, the Middle Ages, Realism, or Naturalism and some of these may never materialize. Progress has been slowed down by the conceptual shifts that comparative literature and the writing of literary histories underwent since 1967 . The first volumes tended to simply line up articles on national literatures side-by-side, leaving the comparison and integration of the rich material to introductions and the reader.

Due to the Cold War and a certain inherent West-European bias, the coverage of geographical Europe itself was for a while rather uneven in the series: of the East-European literatures, for instance, usually only the Russian one was systematically included. The series represented an important step towards globalizing literary history, but it excluded nations and areas where European languages were not official, and, more important, it ignored the native languages in nations and regions where a European language was official. In retrospect, a certain Eurocentric bias colored this laudable move towards globalizing literary history. According to the charter, the volumes could be published in any major European language, and, indeed, six French volumes and one German one has been produced, but due to commercial/financial constraints nonEnglish volumes can now be published only with substantial subsidy. Here, as elsewhere, the globalization of English has given a multicultural project a monolingual bias.

Another conceptual problem of the ICLA project emerged from the WestEuropean orientation of its founders, who considered it self-evident that the break-down of literary history into periods should follow categories used in France, England, and, to a lesser extent, in Germany. Even so, the periods overlap: the series contains volumes on Expressionism and Symbolism, but also on Modernism, five volumes on Romanticism, but also two volumes on the 17601820 period. At the same time, there are also serious gaps: a proposed volume on Naturalism, for instance, has been delayed because of disagreements on a Europe-wide definition of what the term actually means.

Definitions of periods and movements became even more complex once the series gradually expanded its scope within Europe, and the subject matter broadened to include relevant elements of literary culture. It was in reaction to 
NEUBAUER

such problems that I have proposed within the series a "literary culture" subseries covering not all of Europe but only a region. The four-volume History of the Literary Cultures of East-Central Europe (2004-2010) that I have published with my co-editor Marcel Cornis-Pope and some hundred-fifty contributors has meanwhile spawned ongoing projects on the literary history of the Iberian Peninsula and of Scandinavia. The first volume of $A$ Comparative History of Literatures in the Iberian Peninsula (2010) has already been published by Fernando Cabo Aseguinolaza and his coworkers.

I offer the following brief description of our East-Central European project in the hope that some of our ideas could be adapted in coping with the larger problems of literary histories in other parts of the world, including the Far East and South-East Asia. The problems of regional projects start with defining and justifying the coverage. For our project, we have defined East-Central Europe as a narrow strip of land stretching from the Baltic countries to the Balkans, but opinions disagree on the question what to include on eastern and southern sides, and many would argue that Austria should also be included. However, we conceived of the region in terms of imperial dominations from Russia in the East and the German-speaking nations in the West. The southern part has been occupied for centuries by the Ottoman Empire, which has meanwhile been pushed back but left powerful religious and cultural tradition behind.

The region is one of the world's richest multilingual and multicultural areas, but this very richness has led to endemic internal ethnic, religious, and border conflicts. We wanted to put the region's literature on the map for both internal and external readers. Today, the inhabitants of the various nations in East-Central Europe tend to know only their own language and literature, often through the distorting lens of nationalism, Nazism, and Stalinism. Since no independent countries existed in the region around 1800 (the starting date of our history) and only independent, though often unstable, ones after 1989 (our flexible terminal date), national struggles for independence have powerfully shaped the various literatures, and, vice versa, national poets and national literature have played a crucial role in each nation's struggle for independence. National songs, legends, myths, and literature have in Friedrich Schlegel's sense shaped the identity of each nation, but they have also produced historical misunderstandings, military conflicts, and ethnic tensions that led to cultural impoverishment, monolingualism, and monoculture. In the last two hundred years, much of the region's great literature has been written in exile and emigration.

Due to East-Central Europe's specific social, political, and artistic history, West-European period terms have only limited relevance. We divided the region's literary history between 1800 and 1989 into three flexible periods, 
which apply to all the literatures of the region, even if they did not take place simultaneously: (1) National Awakening, (2) Modernism, and (3) Soviet Domination. The first and the third term are specific to the region, while Modernism, adopted from the West, needed to be redefined, because currents from the West entered in East-Central Europe into complex interactions with responses to nineteenth-century nationalism. Modernism opened a window to the world, but the westward gaze could not lose sight of the local ethnic traditions and struggles. We chose "Soviet Domination" as a category for the period 19451989 because the political system during this time reconstituted all aspects of literary life in the region, though not quite uniformly. The cultural policies and the literary lives in the Baltic countries, which were incorporated in the Soviet Union, differed considerably from say Poland, Yugoslavia, Romania, or Albania, where nationalist currents expressed themselves in various forms.

This is not to suggest that national and political issues fully determined the region's literary history. Instead of telling one single literary history, we "scanned" the region's history from five different angles, and only the first scan follows politics closely. Here we show how writers participated in such key events as the revolutions of 1848, the two world wars, the revolutions of 1956 and 1968, and the turnover of 1989-1991, and we analyze the changing memory of these events in literary works. At each of the key dates, conflicting national narrative strands encounter each other, showing alternative perspectives. The second part of the first volume considers the history of literary periods and genres from a specifically regional perspective. We follow, for instance, the emergence of the region's historical novel, and we show East-Central Europe's important contributions to the emergence of such new twentieth-century genres as the reportage, the lyrical novel, fictionalized autobiography, literary theory, and the cabaret.

Our second volume focuses on multilingual and multicultural cities and smaller regions. It includes literary histories of Riga, Budapest, Trieste, Plovdiv and other cities, as well as multicultural regions like Transylvania and the Vilnius region. Such histories do not cross present-day national borders, but they are genuinely transnational and comparative. The innovative and far-reaching implications of this conception, which may be termed "showing the globe in a raindrop," merit further attention. Methodologically, the conception compares with the work of archeologists, who undertake "vertical" border crossings by unearthing different cultural layers at a single site, chronologically crossing thereby cultural layers, some of which reveal monocultures, others a cohabitation of several. Such site-specific cross-cultural diggings may unearth Hun or Etruscan cultural artifacts in Italy, Viking or Celtic remnants in England, Slavic traces in modern Germany, or evidences of the Roman civilization in the 
NEUBAUER

southern part of Europe. Adapting such a model, one could envisage writing literary histories of Paris, London, Berlin, Shanghai, and other metropolitan centers, which would include ethnic, exile, émigré and migrant writing in various tongues.

Adapting such an archeological model would mean, above all, that literary histories should include literatures written not only in the present national language but also in languages that either have died out at the site or still exist in a minority status. The site could well cover the territory of a whole present nation, but the coverage should be transnational. A further development of such site-specific multilingual literary histories could effectively convert adjectival nation designations (e.g., German, Polish, French, or Chinese literature) into geographical ones (literatures written within the border of present-day Germany, Poland, France or China).

Other recent regional literary histories have initiated similar innovations in literary history. The second volume of the Literary Cultures of Latin America: a Comparative History (2004) that Mario Valdés and Djelal Kadir have edited includes twenty-three articles on cultural centers, while the first volume of the mentioned literary history of the Iberian Peninsula includes Jon Kortazar's study on the history of Spanish-Basque cohabitation in Bilbao (222-236). However, the three regions, East-Central Europe, Latin America, and the Iberian Peninsula, face different multilingual, multicultural, and multi-literary problems. The ethnic traditions are still alive in Bilbao, but they have largely disappeared in East-Central Europe because of wide-scale elimination of minorities via forced assimilation, repatriation, the Holocaust and ethnic cleansing, as well as an amnesia concerning the literary culture of such vanished minorities. In Latin America, the shared Spanish and Portuguese language allowed writers, ideas, and literary styles to move from one center to another (Valdés and Kadir 1: xx), whereas linguistic and ethnic differences have limited such a circulation in East-Central Europe.

Regional literatures have started to recuperate the Amerindian literatures in Latin America, the Arab, Jewish, Catalonian, Galician, and Euskadi literatures in the Iberian Peninsula, and the Romani, Sinti, Yiddish, Armenian, and other the minority literatures of East-Central Europe, but national literary histories still tend to ignore works not written in the official language of the country. They may include foreign-born writers, but only if - like Joseph Conrad, Emil Cioran, Samuel Beckett, or Vladimir Nabokov - they had mastered the national language. In the East-Central European region, Romanian literary histories have only recently started to include German- and Hungarian-language literatures, Hungarian literary histories still ignore the once flowering Serbian, Slovak, and Romanian literatures of Pest/Buda, Lithuanian histories exclude 
literary works written in Polish or Yiddish in Vilnius, and Baltic national literary histories disregard works in the Russian language. West-European countries now welcome literary works by migrant workers and their descendants, but, as far as I know, they include them in their national literary histories only if they are written in the country's official language. The monolingualism of present literary histories is well illustrated by the mentioned newer national literary histories: one covers francophone Belgium while the Dutch history also covers Flanders. Migrating writers and literary works carry double passports and should be included in the histories of both their native tongue and their residence. Site-specific literary histories could complement national, European and global approaches by avoiding the pitfalls of both monolingualism and bland globalism. They would differ from archeological excavations because they would have to involve hermeneutic reflections that turn mere chronology into genuine history. By turning the gaze inward and backward, site-specific histories could reveal a teaming and colorful mingling of languages and literatures, a transnational variety of lieux de mémoire. They would counterbalance foundational national epics that lay claim, like Virgil's Aeneid, on a specific site.

The third volume of the literary history in East-Central Europe, titled The Making and Remaking of Literary Institutions, focuses on the institutional structures within which literature is created, distributed, and received. We discuss here publishing, censorship, theater, the uses of folk poetry, and even the writing of literary histories - institutions that were established to further movements towards cultural and political independence. Our final volume, Types and Stereotypes, covers such historical and imaginary figures as national poets, real and imaginary family members, outlaws, and ghost figures like Dracula and the golem. All these types and stereotypes underwent a series of transformations fashioned by the social and national imagination, by processes of canonization, and the emergence of new media.

East-Central European, Iberian, and Scandinavian literary histories modify the very image of Europe by foregrounding the Eastern, Southern, and Northern liminal territories, giving them the recognition that a European literary landscape dominated by the West has ignored. New concepts of European literature ought to abandon the traditional focus on Western and Central Europe, and they ought to question thereby the canonized concepts of literary epochs, genres, and movements, all of which are based on limited notions of European literature, and have fulfilled a colonizing function when applied to the literatures "on the margin". The suggested revision of the balance between central and marginal literary regions within Europe should, at the same time, modify the image of a culturally superior Europe, and neutralize the Eurocentrism that was so obvious in the early decades of comparative literature. Giving 
NEUBAUER

proper recognition to the liminal literatures should also mediate between Europe and its adjacent literary traditions, including the Arab, the Turkish, and the Persian ones and those that emerged from the southern part of the Soviet Union. The projected dispersion will have to question the canonized concepts of literary epochs, genres, and movements. Defined in terms of West-European phenomena, they all became colonizing forces when applied to the literatures "on the margin".

Future European literary histories will have to face, then, the double challenge of revising the image of a culturally superior Europe and of rectifying internal suppressions and imbalances. Initiatives in this direction have been taken not only in the discussed regional histories, but also in a number of other publications and organizations, for instance in a special issue of Comparative Literature on Europe (2006) edited by Susan Suleiman, Theo D'haen's and Iannis Goelandt's Literature for Europe? (2009), and in the "European Network for Comparative Literary Studies.” However, the daunting task of actually writing a comprehensive European literary history has, to my knowledge, not been undertaken recently. Admirable attempts of the past, like Mihály Babits' Az európai irodalom története (1936), would have to be redone with different conceptions and via teamwork. Interestingly, such attempts are being made today on a global scale.

\section{A Globalized Literary History?}

Writing regional literary histories has a twofold significance for globalizing the field: they provide regional models that can be applied to other regions, and they represent concrete steps towards a global conception of literary history. However, as I shall now show, they raise issues that become even more complex on a global scale.

Goethe was not the one who coined the term World Literature, but as David Damrosch shows in What is World Literature? (2003), his reflections on the concept are still stimulating, even if they do not congeal in a single meaning. The problem becomes even more complicated if we reflect on the history of world literature. To paraphrase Kant, comprehensive histories tend to become either encyclopedias without conceptual frames or global generalities lacking local content.

Franco Moretti's theoretical and empirical studies on the novel are, perhaps, the most daring recent attempts to cope with a "embarrassment of riches" in global literary history. Moretti broadens the traditional focus on canonized works and reaches for a quantitatively comprehensive coverage. His testing 
ground is the world history of the novel, of which he had published a five volume Italian collection, the Il romanzo (2001-2003), even before he formulated his theoretical principles in "Conjectures on World Literature" (2004) and in Graphs, Maps, Trees. Abstract Models for a Literary History (2005). The volumes on the novel do not constitute, however, a formal history, and they contain big gaps next to excellent essays on individual works and writers. Here too, the European coverage is clearly biased. East European Nobel Prize winners like Elias Canetti, Isaac Bashevis Singer, and Ivo Andrić are done away with a passing mention, in Andrićs case with the sheer remark that he was one of the greatest novelists of the twentieth century (4:264). Writers from the Baltic countries, the Balkans, Romania, and many other countries and regions are strikingly absent. Hopefully, they will be included in future accounts that Moretti and his team continue to prepare. In his 2004 article, Moretti proposed that, next to traditional close reading, global views of literature also need "distant reading," for this yields fewer elements, and hence a sharper sense of their interconnection ("Conjectures" 151). We do, of course, need interconnections, but "distant reading" may yield schematized overviews, depriving thereby literature of its richness.

Moretti's historical analysis of detective fiction in the "Tree" section of Graphs, Maps, Trees (2005) may serve as an example of his abstract forms, this time adapted from evolutionary biology. The premise here is that genres, subgenres, and stylistic devices like the free indirect discourse change under new historical and social conditions. One would readily consent, if Moretti did not essentialize the meaning of individual works. The mutations that political, social, and market forces bring about are defined with respect to an unchanging original, and history modifies genres but regards the meaning of individual works fixed, though one would expect that later developments of a genre modify also the image of its beginnings.

Other literary historians have more modest aims. Theo D'haen's Concise History of World Literature (2011) is a highly informative introduction to thoughts on world literature and the history of world-literature histories. Though it offers no world-literature history of its own, it includes good summaries of debates on the relevant publications of Moretti and others. One section in the Companion volume, co-edited with David Damrosch and Djelal Kadir (2011), offers a "history of World Literature through significant writers and theorists from Goethe to Said, Casanova and Moretti." A corresponding Reader has been published in 2012. Of the plethora of recent reflections on globalizing literature I can mention here only two collections of essays that Gunilla Lindberg-Wada has edited and published in 2006: Literary History: Towards a Global Perspective and Studying Transcultural Literary History. 
NEUBAUER

While I admire the learning and ingenuity of these new approaches, I cannot help asking whether a full globalization of literary history is viable, and whether the broadening coverage of the world map can adequately represent the cohabitation of literary cultures. We should remember Siegfried Kracauer's objections to writing world histories in general. Using the term Ungleichzeitigkeit des Gleichzeitigen (asynchronicity of the contemporaneous) that the German art historian Wilhelm Pinder had introduced in 1926, Kracauer argues that globalizing the set of simultaneous phenomena will make it inevitably more difficult to bring them together under a common concept, for the various parts of the world run on different clocks ("General History" 569).

Kracauer's point applies to one of the most vexing issues we have already encountered: the difficulty of finding period concepts for broader literary histories. If period concepts coined in Western Europe ill fit East-European phenomena, they are even less applicable elsewhere. As Mario Valdés and Djelal Kadir write in their literary history of Latin America: "all classifications based on European models” break down in sixteenth- and seventeenth-century Latin America (1: xviii). Is it possible to find common period concepts for a globalized history of literature if individual nations, regions, and continents run through such different phases? Concepts like Renaissance, Baroque, Romanticism, or Expressionism can obviously not be globalized.

Traditional literary periods have been based on the internal features of literary works, usually in combination with dominant social and political trends. The problem is twofold: first, internal literary features, social conditions, and political history differ from one language area to another, and secondly, the crossing from one period to another occurs at different points of the time scale. Searching for global parameters, there seems to be no way to resolve the second issue, for it seems impossible to globally synchronize the transitions from one period to the next. However, we may identify a skeletal global structure if we direct our attention to the technologies of writing and communication, which have recently attracted growing interest due to digitalization. In my opinion, the best guide for this is not among recent future-oriented studies but Walter J. Ong's authoritative backward perspective, Orality and Literacy: The Technologizing of the Word (1982). Ong's prime concern is the oral tradition, but he follows its history through the periods of handwriting, and printing, stopping short of digital word processing. As his title indicates, this is a technological history of words and literature, but Ong, as well as others, insists that the changing technologies have defined not only how but also what is being written: "writing restructures consciousness" (Ong 77). Of course, inventing the alphabet, printing, and the computer offer only four very general periods, but each of these can be broken down into subdivisions. Ong, for instance, speaks 
of a secondary orality, based on the invention of film, photography and telephone, while Friedrich Kittler, who juxtaposes the Aufschreibesysteme (systems of writing) around 1800 and 1900, ascribes the transformation around 1900 largely to the emergence of the typewriter.

It is in this sense that Wilt Idema and Lloyd Haft have distinguished already in a 1996 Dutch introduction to Chinese literature between four major periods in Chinese literary history: 1) the period of orality that ends with the invention of paper around 100 A.D.; 2) a period of handwriting that ends with the general spread of book printing around 1000 A.D., 3) a third one that ends with the introduction of lithography and other modern printing techniques around 1875; and 4) the period after 1875 (Idema 22). Because of the specificity of the Chinese signs and the independence of Chinese history, these periods do not coincide chronologically with the key dates of word technology elsewhere, but the stages are nevertheless the same and may offer mileposts for a global view of literary history.

While all literary works can be placed into the suggested sequence of global period concepts, this alone does not yield rich interconnections. I want to distinguish between two basic comparative methods, and illustrate each with an article that compares Chinese and German literary works. Both will appear in the next issue of arcadia, a journal of comparative literature of which Professor Vivian Liska and I are co-editors. The first one, by Johannes D. Kaminski, combines a joint study of Cao Xueqin's Hong Lou Meng and Johann Wolfgang Goethe's Wilhelm Meisters Lehrjahre, both first printed in the 1790s, with reflections about the possibilities and limitations of comparing literary works that had no historical contacts between them. Kaminski focuses on the function of mythological metanarratives in the two novels and shows, above all, the differences. The second one, by Arne Klawitter, studies the adaptation of the Chinese Shijing by German poets who knew no Chinese. In this case, historical contacts exist, but they are questionable: the expressionist poet Albert Ehrenstein published a German adaptation that he called not translation but Nachdichtung, a sort of free reformulation of the Chinese originals. Klawitter suggests that it was actually an Umdichtung, a refunctionalization of the poems under radically different circumstances. Of course, Ehrenstein was severely taken to task by critics, among them Chen Chuan, who claimed in his doctoral dissertation that Ehrenstein's "bombastic" and "pathos-laden" poems did not do justice to the original ones (104). Chuan, who later became Professor of German literature in Kunming and at other Chinese universities, was, in a sense, right, but he failed to understand that Ehrenstein reused the originals to attack in the 1920s the social injustices of his own society. 
NEUBAUER

Here we touch on fundamental questions of adaptation. Chuan's premise was that fidelity to the original is the only valid criterion to judge adaptations. Although many critics still insist on such a fidelity, attitudes towards adaptation have drastically changed in the last decades and most people recognize today that adaptations and sophisticated imitations can fulfil new and innovative functions. Witness the greater freedom granted to translators and stage directors, but also the burgeoning studies on adaptations of novels to film, television and other media. The central thesis of Linda Hutcheon's book A Theory of Adaptation (2006) is precisely that we should not judge adaptations by their fidelity to the original, and not belittle works just because they are adaptations rather than original works. The latter point is beautifully thematized already in Chapter 17 of Cao Xueqin's Hong Lou Meng. In preparation of the Imperial Concubine's brief return home, her family sets up sumptuous gardens and buildings, which need to be decorated with poems. Jia Zheng invites a number of distinguished poets for this baptism, but delegates the leading role to his son Bao-yu, not because he thinks so highly of him but because he is eager to criticize his offspring. At a building of "quite another order of elegance," Jia Zheng challenges Bao-yu to come up with poetic lines, but belittles the result as imitation. The literary gentlemen disagree: "There is nothing wrong with imitation provided it is done well. After all, Li Bo's poem 'On the Phoenix Terrace' is entirely based on Cui Hao's 'Yellow Crane Tower', yet it is a much better poem" (Cao 342). They defend thereby a poetics that dominated not only classical Chinese poetry, but also such Western traditions as Petrarchism and Baroque poetry. Romanticism turned against such traditions by championing originality and genius, but the romantic tradition was itself saturated with adaptations.

Works of literature and other works of art are neither fixed nor eternal but constantly change. Oral poetry, which started to use language for artistic purposes, had no original standard but consisted of performances that were constantly revised, passed on, and readapted to suit new audiences. Converting oral poetry into written texts, a momentous process of adaptation, certainly did not give texts a standard form, as Hong Lou Meng itself demonstrates all too well. Hence, I propose that a broadened notion of adaptation could become the very heart of a global concept of literary history. Such a broadened conception would recognize not only that literary works are constantly reshaped by new historical, cultural, and social contexts but also that new philological shapes emerge via re-edition (or even digitalization) of texts; adaptations via translations, staging, musical setting, and visual illustrations. Literary works constantly mutate, and this endless process of adaptation constitutes a global literary history that crosses the borders of historical periods and national cultures. 
Globalizing Literary History

\author{
John Neubauer \\ johnneubauer329@gmail.com \\ Keizersgracht 734F \\ 1017 EW Amsterdam \\ NEDERLAND
}

\title{
References
}

Arnold, J. A., ed. 1994-2001. History of Literature in the Caribbean [3 vols]. Amsterdam: Benjamins.

Babits, M. 1936. Az európai irodalom története [History of European Literature]. Budapest: Nyugat.

Beöthy, Z. 1896. A magyar irodalom kis-tükre [Little Mirror of Hungarian Literature]. Budapest: Athenaeum.

Cabo Aseguinolaza, F., Gonzalez, A. A., Domínguez, C., eds. 2010. A Comparative History of Literatures in the Iberian Peninsula. Vol. 1. Amsterdam: Benjamins.

Cao Xueqin. 1973. The Story of the Stone [D. Hawkes, transl.]. Vol. 1. London: Penguin.

Chen Chuan. 1933. Die chinesische schöne Literatur im deutschen Schrifttum. Diss. Kiel.

Chmielowski, P. 1899-1900. Historia literatury polskiej [6 vols]. Warsaw: Biblioteka Dzieł Wyborowych.

Cornis-Pope, M., Neubauer, J., eds. 2004-2010. History of the Literary Cultures of EastCentral Europe [4 vols]. Amsterdam: Benjamins.

Damrosch, D. 2003. What is World Literature? Princeton: Princeton UP.

De Sanctis, F. 1870-1871. Storia della letteratura italiana [2 vols]. Morano: Napoli.

D'haen, Th., Goerlandt, I., eds. 2009. Literature for Europe? Amsterdam: Rodopi.

D’haen, Th., Domínguez, C., Rosendahl Thomsen, M., eds. 2012. World Literature, A Reader. London: Routledge.

D’haen, Th., Damrosch, D., Kadir, D. 2011. The Routledge Companion to World Literature. London: Routledge.

D'haen, Th. 2011. The Routledge Concise History of World Literature. London: Routledge.

Ehrenstein, A. 1922. Schi-King. Nachdichtungen chinesischer Lyrik. Vienna: Tal.

Foucault, M. 1973. The Order of Things. An Archeology of the Human Sciences. New York: Vintage. [Transl. of Les mots et les choses. Une archéologie des sciences humaines. Paris: Gallimard, 1966.]

Gérard, A., ed. 1986. European-language Writing in Sub-Saharan Africa. 2 vols. Budapest: Akadémiai Kiadó.

Gervinus, G. G. 1835-1842. Geschichte der poetischen National-Literatur der Deutschen [5 vols]. Leipzig: Engelmann.

Giles, H. 1901. History of Chinese Literature. New York: Appleton.

Goethe, J. W. 1988. Wilhelm Meisters Lehrjahre. 1795-96. Sämtliche Werke. Vol. 5. Munich: Hanser. 
NEUBAUER

Grube, W. 1902. Geschichte der chinesischen Literatur. Leipzig: Amelangs.

Hollier, D., ed. 1993. De la littérature française. Paris: Bordas. [Transl. and rev. ed. of $A$ New History of French Literature. Cambridge: Harvard UP, 1989.]

Hutcheon, Linda. 2006. A Theory of Adaptation. New York: Routledge.

Idema, W., Haft, L. 1996. Chinese Letterkunde: Een Inleiding. Amsterdam: Amsterdam UP.

Jauss, H. R. 1970. Literaturgeschichte als Provokation der Literaturwissenschaft [1967]. - Literaturgeschichte als Provokation. Frankfurt/M.: Suhrkamp, 144-207.

Kaminski, J. D. 2013. Myths We Cannot Believe In: The Function of Mythological Metanarratives in Wilhelm Meisters Lehrjahre and Hong Lou Meng. - arcadia 48.1 [forthcoming]

Kittler, F. A. 1985. Aufschreibesysteme 1800/1900. Munich: Fink. [Transl. M. Metteer, Ch. Cullens as Discourse Networks 1800/1900. Stanford: Stanford UP, 1990.]

Klawitter, A. 2013. Wie man chinesisch dichtet, ohne Chinesisch zu verstehen. Deutsche Nach- und Umdichtungen chinesischer Lyrik von Rückert bis Ehrenstein. - arcadia 48.1 [forthcoming].

Kracauer, S. 1968. General History and the Aesthetic Approach. - H. R. Jauss, ed., Die nicht mehr schöne Künste. Munich: Fink, 111-127; 559-581.

Lanson, G. 1894. Histoire de la littérature française. Paris: Hachette.

Lindberg-Wada, G., ed. 2006. Literary History: Towards a Global Perspective [4 vols]. Berlin: de Gruyter.

Lindberg-Wada, G., ed. 2006. Studying Transcultural Literary History. Berlin: de Gruyter.

Marcus, G., Sollors, W., eds. 2009. A New Literary History of America. Cambridge: Harvard UP.

Moretti, F., ed. 2001-2003. Il Romanzo [5 vols]. Torino: Einaudi.

Moretti, F. 2004. Conjectures on World Literature. - Ch. Prendergast, ed., Debating World Literature. London: Verso, 148-162.

Moretti, F. 2005. Graphs, Maps, Trees. Abstract Models for a Literary History. London: Verso.

Ong, W. J. 2002. Orality and Literacy: The Technologizing of the Word [1982]. London: Routledge.

Perkins, D. 1992. Is Literary History Possible? Cambridge: Harvard UP.

Pinder, W. 1926. Das Problem der Generation in der Kunstgeschichte Europas. Berlin: Frankfurter Verlags-Anstalt.

Schenkenveld-van der Dussen, M. A., ed. 1993. Nederlandse Literatuur, een geschiedenis. Groningen: Nijhoff.

Schlegel, F. 1961. Geschichte der alten und neuen Literatur [1815]. Kritische FriedrichSchlegel Ausgabe. Vol. 6 [H. Eichner, ed.]. Paderborn: Schöningh.

Suleiman, S. R., ed. 2006. The Idea of Europe. Special issue, Comparative Literature 58.4 .

Szegedy-Maszák, M. et al., eds. 2007. A magyar irodalom történetei [The Histories [Stories] of Hungarian Literature, 3 vols]. Budapest: Gondolat.

Taine, H. 1863-1864. Histoire de la littérature anglaise [4 vols]. Paris: Hachette. 
Globalizing Literary History

Tynyanov, Y. 1969. Über die literarische Evolution [1927]. - J. Striedter, ed., Texte der Russischen Formalisten. Munich: Fink, 432-461.

Valdés, M., Kadir, D., eds. 2004. Literary Cultures of Latin America: a Comparative History [3 vols]. Oxford: Oxford UP.

Wellbery, D. A. et al., eds. 2004. A New History of German Literature. Cambridge, MA: Harvard UP.

Wellek, R., Warren, A. 1948. Theory of Literature. $3^{\text {rd }}$ ed. New York: Harcourt Brace, 1956.

Wellek, R. 1982. The Fall of Literary History [1973] - The Attack on Literature and Other Essays. Chapel Hill: U of North Carolina P, 64-77.

Wellek, R. 1955-1992. A History of Modern Criticism: 1750-1950 [8 vols]. New Haven: Yale UP. 